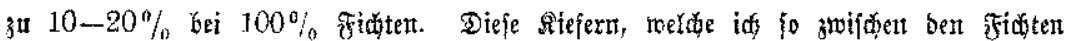

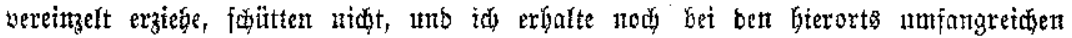

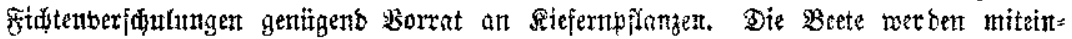

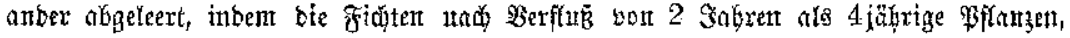

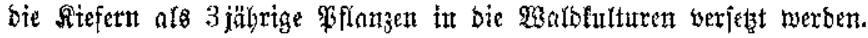

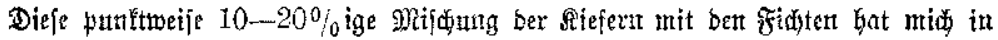

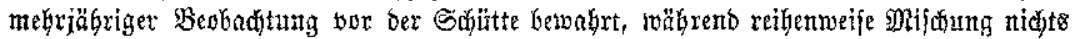

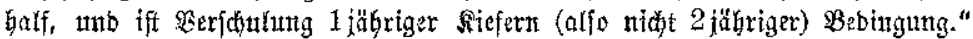

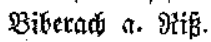

Siģler, Sigl. Sherfürfter.

\title{
Eidhenlohrittde=Deriteigerung in Kaiferslautern.
}

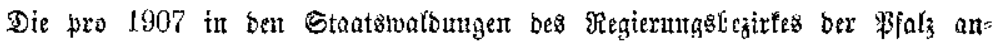

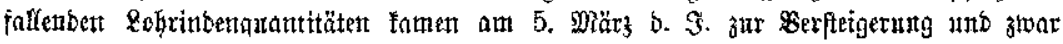

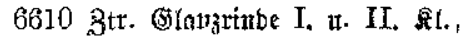

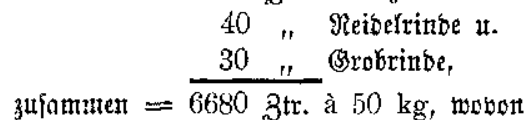

1100 3tr. won Stodianglalag untex 18 3abren u.

$5580 "$ " " illur 18 Sahre.

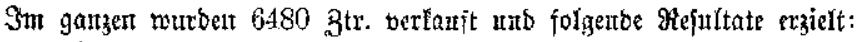

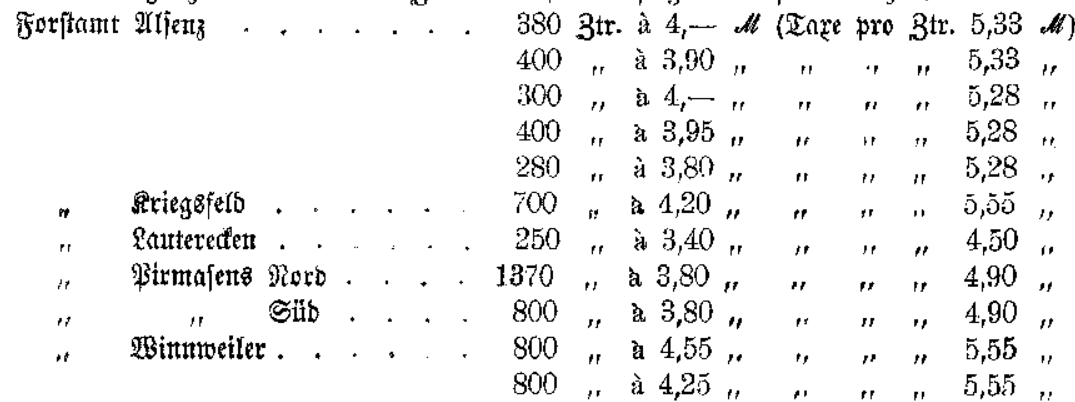

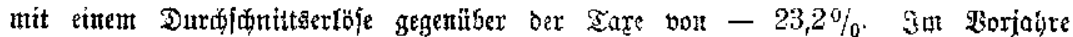
mutben 4580 3tr. Robrittbe mit einem (5ejamterlüje von - 38\% gegenïber ber Taçe bertionft.

Der Mehrerï̈s gegeniitber 1906 beträgt $=15 \%$.

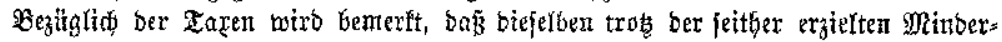

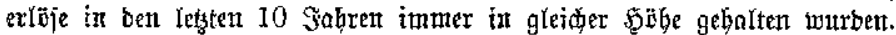

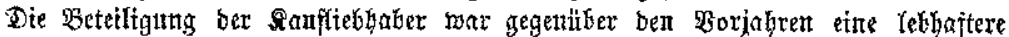
und fint infolgebeffen auth bie erzielten Erläị nentenstwert bähere. 